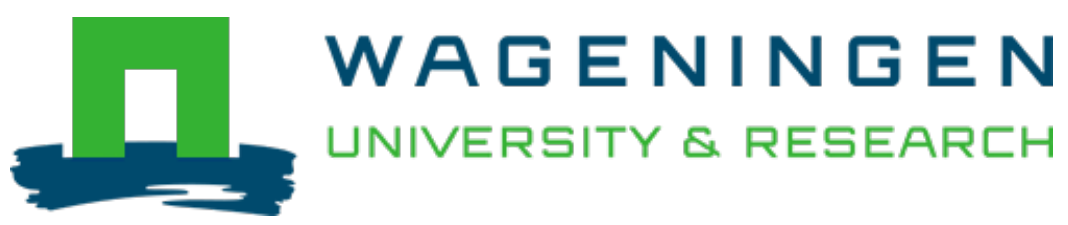

\title{
Bioactivity of tempe by inhibiting adhesion of ETEC to intestinal cells, as influenced by fermentation substrates and starter pure cultures
}

\author{
Food Microbiology \\ Roubos-van den Hil, P.J.; Nout, M.J.R.; Meulen, J.; Gruppen, H. \\ https://doi.org/10.1016/j.fm.2010.02.008
}

This publication is made publicly available in the institutional repository of Wageningen University and Research, under the terms of article $25 \mathrm{fa}$ of the Dutch Copyright Act, also known as the Amendment Taverne. This has been done with explicit consent by the author.

Article 25 fa states that the author of a short scientific work funded either wholly or partially by Dutch public funds is entitled to make that work publicly available for no consideration following a reasonable period of time after the work was first published, provided that clear reference is made to the source of the first publication of the work.

This publication is distributed under The Association of Universities in the Netherlands (VSNU) 'Article $25 \mathrm{fa}$ implementation' project. In this project research outputs of researchers employed by Dutch Universities that comply with the legal requirements of Article $25 \mathrm{fa}$ of the Dutch Copyright Act are distributed online and free of cost or other barriers in institutional repositories. Research outputs are distributed six months after their first online publication in the original published version and with proper attribution to the source of the original publication.

You are permitted to download and use the publication for personal purposes. All rights remain with the author(s) and / or copyright owner(s) of this work. Any use of the publication or parts of it other than authorised under article $25 \mathrm{fa}$ of the Dutch Copyright act is prohibited. Wageningen University \& Research and the author(s) of this publication shall not be held responsible or liable for any damages resulting from your (re)use of this publication.

For questions regarding the public availability of this publication please contact openscience.library@wur.nl 


\title{
Bioactivity of tempe by inhibiting adhesion of ETEC to intestinal cells, as influenced by fermentation substrates and starter pure cultures
}

\author{
Petra J. Roubos-van den Hil ${ }^{\mathrm{a}, \mathrm{b}, *}$, M.J. Rob Nout ${ }^{\mathrm{a}}$, Jan van der Meulen ${ }^{\mathrm{c}}$, Harry Gruppen ${ }^{\mathrm{b}}$ \\ ${ }^{a}$ Laboratory of Food Microbiology, Wageningen University, Bomenweg 2, 6703 HD Wageningen, The Netherlands \\ ${ }^{\mathrm{b}}$ Laboratory of Food Chemistry, Wageningen University, Bomenweg 2, 6703 HD Wageningen, The Netherlands \\ ${ }^{\mathrm{C}}$ Animal Sciences Group, Wageningen University and Research Centre, Edelhertweg 15, 8219 PH Lelystad, The Netherlands
}

\section{A R T I C L E I N F O}

\section{Article history:}

Received 8 December 2009

Received in revised form

22 February 2010

Accepted 27 February 2010

Available online 9 March 2010

\section{Keywords}

Tempe

Starter cultures

Substrates

Bioactivity

ETEC

Adhesion

\begin{abstract}
A B S T R A C T
Soya bean tempe is known for its bioactivity in reducing the severity of diarrhoea in piglets. This bioactivity is caused by an inhibition of the adhesion of enterotoxigenic Escherichia coli (ETEC) to intestinal cells. In this paper, we assessed the bioactive effect of soya tempe on a range of ETEC target strains, as well as the effect of a range of cereal and leguminous substrates and starter pure cultures.

Soya bean tempe extracts strongly inhibited the adhesion of ETEC strains tested. All tempe made from other leguminous seeds were as bioactive as soya bean tempe, whereas tempe made from cereals showed no bioactivity. Using soya beans as substrate, fermentation with several fungi (Mucor, Rhizopus spp. and yeasts) as well as Bacillus spp. resulted in bioactive tempe, whereas fermentation with lactobacilli showed no bioactivity.

The active component is released or formed during the fermentation and is not present in microbial biomass and only partly in unfermented substrates. The bioactivity being not specific for a single ETEC strain, makes the bioactive tempe relevant for applications in animal husbandry.
\end{abstract}

(C) 2010 Elsevier Ltd. All rights reserved.

\section{Introduction}

Tempe is a fungal fermented food originating from Indonesia, which is made mostly from soya beans through fermentation with Rhizopus spp. (Nout and Kiers, 2005). In the final product the cottony mycelium binds the soya beans together to a compact cake. During fermentation of soya beans, a range of fungal enzymes is produced including proteases, lipases, carbohydrases and phytases. These enzymes degrade macromolecules into lower molecular weight substances, thus partly solubilizing the cell walls and intracellular material, leading to an increased nutritional quality and digestibility (Nout and Kiers, 2005). Previous research showed that tempe made from soya beans fermented with Rhizopus microsporus, can reduce the severity of diarrhoea in piglets (Kiers et al., 2003). This effect of soya bean tempe is obtained by inhibition of the adhesion of enterotoxigenic Escherichia coli (ETEC) to intestinal brush border cells (Roubos-van den Hil et al., 2009). Reduced adhesion of ETEC strains to intestinal cells results in

\footnotetext{
* Corresponding author at: Laboratory of Food Microbiology, Wageningen University, Bomenweg 2, 6703 HD Wageningen, The Netherlands. Tel.: +31 317 484982; fax: +31317 484978 .

E-mail address: petra.roubos@wur.nl (P.J. Roubos-van den Hil).
}

reduced colonization and enterotoxin production, manifested by a lower diarrhoeal incidence (Nataro and Kaper, 1998).

The present work was performed to determine whether the use of different substrates and starter pure cultures do influence this bioactivity of tempe. In addition it is determined whether this bioactivity is generic for other ETEC strains. This would give more information about the bioactive component and applicability of the tempe bioactivity.

Previous research (Kiers et al., 2002; Roubos-van den Hil et al., 2009) was performed using a single ETEC target strain as a model to investigate adhesion inhibition. No published data on the inhibition of adhesion of different ETEC strains is available. Therefore, the first aim of the present study was to test tempe bioactivity against a wide range of ETEC bacteria isolated from piglets with diarrhoea.

Tempe is considered as the collective name for various pulses and cereals fermented with a fungi belonging to the Rhizopus genus. Traditionally, tempe is made from soya beans and, therefore, most research is done with soya bean tempe. However, other substrates such as barley (Eklund-Jonsson et al., 2006; Feng et al., 2007a), chick pea (Ashenafi and Busse, 1991), cowpea (Egounlety, 2001; Kiers et al., 2000a), groundbean (Egounlety, 2001), horse bean (Ashenafi and Busse, 1991), pea (Ashenafi and Busse, 1991), oats (Eklund-Jonsson et al., 2006), sorghum (Mugula and Lyimo, 2000) and wheat 
(Hachmeister and Fung, 1993) were also reported to be suitable substrates to produce tempe. The impact of using different substrates on the adhesion inhibition was not investigated before. Hence, the second aim of this research was to determine the bioactivity of tempe prepared with different leguminous and cereal substrates. Thereby several fermentation parameters were determined to confirm a successful fermentation of the different products into a tempe product.

A diverse range of microorganisms may be encountered in tempe, including filamentous fungi involved in the inoculation and fermentation of tempe, as well as high levels of bacteria and yeasts (Nout and Rombouts, 1990). Research on the microbial quality of commercial tempe in The Netherlands showed that most samples had an aerobic plate count exceeding $10^{7} \mathrm{CFU} \mathrm{g}^{-1}$, with lactic acid bacteria over $10^{7} \mathrm{CFU} \mathrm{g}{ }^{-1}$ and yeast levels higher than $10^{5} \mathrm{CFU} \mathrm{g}^{-1}$ in $69 \%$ of the samples (Samson et al., 1987). While the contribution of these bacteria and yeasts to the properties of tempe is only partly understood, they do play a role in flavour development and chemical substrate modification (Nout and Rombouts, 1990). Lactic acid bacteria were shown to play a role in acidification of the soya beans during soaking, thereby preventing the growth of spoilage causing microorganisms (Nout et al., 1987). In order to research the origin and formation of the bioactive principle, the third aim of this research was to test the bioactivity of soya beans inoculated with different microorganisms (isolated from tempe and similar fermented products) and to monitor their growth during fermentation.

\section{Materials and methods}

\subsection{Microorganisms}

Ten ETEC K88 strains and one ETEC K91 strain (for serotypes see Table 1) were grown in brain heart infusion (BHI) broth (Becton Dickinson, 237500) at $37{ }^{\circ} \mathrm{C}$ overnight. The strains were provided by the collection of the Animal Science Group, Lelystad, Wageningen University and Research Centre, The Netherlands. The cultures were centrifuged $(3000 \mathrm{~g}, 10 \mathrm{~min})$ and washed twice with phosphatebuffered saline (PBS) ( $\mathrm{NaCl} 136.89 \mathrm{mM}, \mathrm{KCl} 2.68 \mathrm{mM}, \mathrm{Na}_{2} \mathrm{HPO}_{4}$ $8.1 \mathrm{mM}, \mathrm{KH}_{2} \mathrm{PO}_{4} 2.79 \mathrm{mM}, \mathrm{pH} 7.2$ ), followed by suspending the pellets in PBS, to an optical density of 0.75 corresponding with

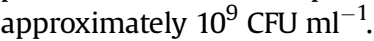

For fermentation, 2 Lactobacillus, 8 mould, 3 Bacillus and 7 yeast strains from the Laboratory of Food Microbiology, Wageningen University, Wageningen, The Netherlands were used (Table 2). Lactobacillus strains were maintained on de Man, Rogosa and Sharpe (MRS) agar plates (Becton Dickinson, 288130). Two days before use in experiments the strains were inoculated in MRS broth and incubated at $30^{\circ} \mathrm{C}$. The cultures were then washed and diluted

Table 1

ETEC strains.

\begin{tabular}{lll}
\hline Strain no. $^{\mathrm{a}}$ & Serotype & Toxins \\
\hline ID 1000 & O149:K91:K88 & Oc \\
ID 1002 & O149:K91:K88 & LT, STb \\
ID 1006 & O149:K91:K88 & LT, STb \\
ID 1008 & O149:K91:K88 & LT, STb \\
ID 1009 & O8:K87:K88 & LT, STb \\
ID 1010 & O138:K81:K88 & LT, STb \\
ID 1012 & O8:K87:K88 & LT, STb \\
ID 1018 & O138:K81:K88 & LT, STb \\
ID 1022 & O138:K81:K88 & LT, STb \\
ID 1063 & O8:K87:K88 & LT, STb \\
ID 1084 & O149:K91 & LT, STb \\
\hline
\end{tabular}

a Strains were obtained from the collection of the Animal Sciences Group, Wageningen University and Research Centre, Lelystad, The Netherlands.
Table 2

Microorganisms used for soya bean fermentation.

\begin{tabular}{|c|c|c|}
\hline Strain no. ${ }^{a}$ & Name & Isolated from \\
\hline \multicolumn{3}{|l|}{ Lactobacillus } \\
\hline LU 848 & Lactobacillus plantarum & Soya soak water \\
\hline LU 852 & Lactobacillus plantarum & Soya soak water \\
\hline \multicolumn{3}{|l|}{ Bacillus } \\
\hline LU 810 & Bacillus licheniformis & \\
\hline LU 812 & Bacillus pumilus & \\
\hline LU 814 & Bacillus subtilis & \\
\hline \multicolumn{3}{|l|}{ Yeasts } \\
\hline LU 121 & Candida intermedia & Tempe \\
\hline LU 502 & Pichia guilliermondii & Tempe \\
\hline LU 677 & Saccharomycopsis fibuligera & Ragi \\
\hline LU 692 & Trichosporon beigelii & Tempe \\
\hline LU 1251 & Saccharomyces cerevisiae & Rice wine \\
\hline LU 1253 & Candida glabrata & Rice wine \\
\hline \multicolumn{3}{|l|}{ Moulds } \\
\hline LU 361 & Mucor circinelloides (f. circ.) & Tempe \\
\hline LU 365 & Mucor indicus & Tempe \\
\hline LU 573 & Rhizopus microsporus & Tempe \\
\hline LU 575 & Rhizopus oligosporus & Tempe \\
\hline LU 581 & Rhizopus oryzae & Tempe \\
\hline LU 2036 & Rhizopus microsporus & Sufu \\
\hline LU 2040 & Rhizopus oligosporus & Rice wine starter \\
\hline LU 2041 & Rhizopus oryzae & Rice wine starter \\
\hline
\end{tabular}

a Strains were obtained from the Laboratory of Food Microbiology, Wageningen University, Wageningen, The Netherlands.

in peptone physiological salt solution (PPS), containing neutralized bacteriological peptone $1 \mathrm{~g} \mathrm{l}^{-1}$ (Oxoid, LP34) and $\mathrm{NaCl} 8.5 \mathrm{~g} \mathrm{l}^{-1}$, to approximately $10^{6} \mathrm{CFU} \mathrm{ml^{-1 }}$. Bacillus strains were maintained on BHI agar. One day before the start of the experiment the strains were inoculated in $\mathrm{BHI}$ broth and incubated at $30^{\circ} \mathrm{C}$ while shaking at $200 \mathrm{rpm}$. The cultures were washed and diluted in PPS to approximately $10^{6} \mathrm{CFU} \mathrm{ml}^{-1}$. Yeast strains were maintained on Malt Extract Agar (MEA) (Oxoid, CM59). Two days before the start of the experiment strains were inoculated in Malt Extract Broth (MEB) (Oxoid, CM57) and incubated at $30{ }^{\circ} \mathrm{C}$ while shaking at $200 \mathrm{rpm}$. The cultures were washed and diluted in PPS to approximately

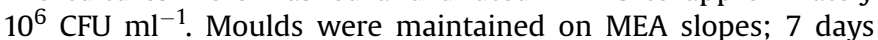
before the start of the experiment they were inoculated on fresh MEA slopes and incubated at $30{ }^{\circ} \mathrm{C}$. A spore suspension was prepared by adding $10 \mathrm{ml}$ PPS per slope and releasing the sporangia to obtain a suspension with a concentration of $10^{5}-10^{6} \mathrm{CFU} \mathrm{ml}{ }^{-1}$.

\subsection{Tempe fermentation with different substrates and Rhizopus spp.}

Soya beans (yellow-skinned variety used for tempe making (USA), normal and organically farmed), cowpea (Benin, West Africa), green pea, red bean, wheat, oat and barley (all from local stores the Netherlands) were use as substrates for fermentation. Substrates were soaked overnight in tap water at $30^{\circ} \mathrm{C}$. In order to achieve an accelerated lactic acid fermentation during this soaking step, the soak water had been inoculated with naturally acidified soaking water ("backslop") (Nout et al., 1987). Next, the substrates were rinsed with tap water and cooked in fresh tap water for $20 \mathrm{~min}$ at a substrate:water ratio of $1: 3(\mathrm{w} / \mathrm{v})$. Subsequently, the substrates were cooled and surface dried at room temperature, and were spread out on mesh trays for about $1 \mathrm{~h}$. For the fungal inoculation of the substrates a sporangiospore suspension from pure slant cultures of $R$. microsporus var. microsporus (LU 573) was used. After inoculation with the spore suspension $\left(10 \mathrm{ml} \mathrm{kg}^{-1}\right)$, the substrates (batches of $450 \mathrm{~g}$ ) were packed into hard-plastic, perforated boxes $(205 \times 90 \times 45 \mathrm{~mm})$ and incubated for $48 \mathrm{~h}$ at 
$30{ }^{\circ} \mathrm{C}$. Cooked and fermented substrates were stored and used for analyses.

\subsection{Soya bean fermentation with different microbial inoculants}

Soya beans were soaked overnight in tap water at $4{ }^{\circ} \mathrm{C}$ (bean: water ratio $1: 3(\mathrm{w} / \mathrm{v}))$ to avoid fermentative acidification. Beans were washed and subsequently cooked for $20 \mathrm{~min}$ in fresh tap water. After cooking, the beans were cooled and surface dried at room temperature. Next, $100 \mathrm{~g}$ of beans were transferred into glass jars and sterilized at $121{ }^{\circ} \mathrm{C}$ for $30 \mathrm{~min}$. After cooling to room temperature the beans were inoculated with $5 \mathrm{ml}$ of the diluted microbial cultures (Table 2). After mixing, the beans were incubated aerobically for $48 \mathrm{~h}$ at $30^{\circ} \mathrm{C}$.

\section{4. $\mathrm{pH}$ measurement and microbiological analyses}

Cooked and fermented samples ( $5 \mathrm{~g}$ ) were mixed with $45 \mathrm{ml}$ PPS and homogenized in a stomacher (Seward stomacher circulator 400; $1 \mathrm{~min} ; 200 \mathrm{rpm}$ ). The $\mathrm{pH}$ was measured in this suspension with a $\mathrm{pH}$ meter (WTW digital pH meter 525 with electrode Sentix 4.1). Further decimal dilutions in PPS were prepared and plated on appropriate growth agars. Fermented samples from different substrates were plated on plate count agar (PCA) (Oxoid, CM325) for total viable count and on MRS-agar for lactic acid bacteria (LAB) count. The beans incubated with different microorganisms were plated on the same media as had been used for their cultivation. Plates were incubated for $24 \mathrm{~h}$ at $30^{\circ} \mathrm{C}$; MRS-plates were incubated anaerobically. The development of the mould mycelium and appearance of the tempe cakes after incubation were assessed visually.

\subsection{Dry matter content and solubility}

Dry matter content was determined by freeze drying $50 \mathrm{~g}$ of the samples. Freeze-dried samples were ground to a fine flour (Ultra Centrifugal Mill ZM 200, Retsch GmbH, Haan, Germany) passing through a $0.5 \mathrm{~mm}$ sieve. Solubility was arbitrarily defined as the dissolving capacity of $5 \mathrm{~g}$ sample in $100 \mathrm{ml}$ water using subsequent extractions. It was quantified by suspending $5 \mathrm{~g}$ of freeze-dried sample in $50 \mathrm{ml}$ distilled water and incubating at $37^{\circ} \mathrm{C}$ for $30 \mathrm{~min}$ with continuous shaking. After centrifugation $(2600 \mathrm{~g} ; 15 \mathrm{~min}$, $4{ }^{\circ} \mathrm{C}$ ), supernatants were collected and pellets were re-suspended with $20 \mathrm{ml}$ of distilled water and centrifuged. This re-suspension step was repeated once. The supernatants collected from the three centrifugation steps were pooled and adjusted to $100 \mathrm{ml}$. Ten $\mathrm{ml}$ of this solution was oven-dried at $80^{\circ} \mathrm{C}$ for $24 \mathrm{~h}$, from which dissolved dry matter was calculated. The remaining $90 \mathrm{ml}$ was freeze-dried and used for subsequent experiments.

\subsection{Protein degradation}

Total nitrogen contents of the various samples were determined in duplicate by the Dumas method using an NA2100 Nitrogen and Protein Analyzer (CE INSTRUMENTS) according to the manufacturer's instructions; methionine was used as a standard. The degradation of proteins was measured by formol titration of terminal (free) amino nitrogen. Freeze-dried ground samples were weighed $(1.0 \mathrm{~g})$ and suspended in $25 \mathrm{ml}$ distilled water with continuous stirring. The $\mathrm{pH}$ was adjusted to 8.5 with $0.1 \mathrm{M} \mathrm{NaOH}$ and $5 \mathrm{ml}$ formaldehyde (35\%) solution ( $\mathrm{pH}=8.5$ ) was added and left for $2 \mathrm{~min}$ for the reaction to take place. The solution was titrated back to $\mathrm{pH} 8.5$ with $0.1 \mathrm{M} \mathrm{NaOH}$. The used volume in the titration was directly proportional to the amount of free amino nitrogen (Han et al., 1999). The formol value expressed as free amino nitrogen gives an indication of the hydrolysis of proteins.

\subsection{Reducing sugars}

Reducing sugars were determined according to Nelson-Somogyi (Green et al., 1989). Briefly, $1.0 \mathrm{~g}$ of freeze-dried ground samples was suspended in $25 \mathrm{ml}$ distilled water with continuous stirring for $1 \mathrm{~h}$. Samples $(450 \mu \mathrm{l})$ were mixed with $450 \mu \mathrm{l}$ copper reagent, consisting of 4 parts of $\mathrm{K}-\mathrm{Na}$-tartrate: $\mathrm{Na}_{2} \mathrm{CO}_{3}: \mathrm{Na}_{2} \mathrm{SO}_{4}: \mathrm{NaHCO}_{3} \quad(1: 2: 12: 1.3)$ and 1 part of $\mathrm{CuSO}_{4} \cdot 5 \mathrm{H}_{2} \mathrm{O}: \mathrm{Na}_{2} \mathrm{SO}_{4}$ (1:9). The first reagent was prepared by boiling to completely dissolve the components. The samples were cooked for $10 \mathrm{~min}$ and cooled to room temperature. Arsenomolybdate reagent was prepared by mixing $26.5 \mathrm{~g}$ ammoniummolybdate in $450 \mathrm{ml}$ distilled water with addition of $21 \mathrm{ml}$ concentrated $\mathrm{H}_{2} \mathrm{SO}_{4}$ and $3 \mathrm{~g}$ of $\mathrm{Na}_{2} \mathrm{HAsO}_{4} \cdot 7 \mathrm{H}_{2} \mathrm{O}$ in $25 \mathrm{ml}$ distilled water and this solution was incubated for $24 \mathrm{~h}$ at $37^{\circ} \mathrm{C}$. Prior to use, 1 part of this solution was mixed with 2 parts of $1.5 \mathrm{M} \mathrm{H}_{2} \mathrm{SO}_{4}$ and $450 \mu \mathrm{l}$ of this reagent was added to the samples and mixed. After $30 \mathrm{~min}$ $3 \mathrm{ml}$ of distilled water was added and the absorption was measured at $520 \mathrm{~nm}$. For the calibration glucose was used in a concentration of $0-150 \mu \mathrm{g} \mathrm{ml} \mathrm{m}^{-1}$.

\subsection{Bioactivity assay}

Bioactivity of the different products was measured with the brush border adhesion assay. Brush border cells were isolated from the jejunum of a K88-receptor positive, early weaned six week old piglet were used according to Sellwood et al. (1975). The brush border cells were exposed to ETEC K88 (ID1000) to confirm positive receptor status; brush borders that bound more than 8 ETEC K88 per brush border cell were recorded as K88-positive. In our experiments, we also used a non-adhering E. coli (O149:K91) strain ID 1084 as a negative non-adhering control.

Freeze-dried soluble extracts (10 mg) were dissolved in $1 \mathrm{ml}$ PBS, mixed in a head-over-tail rotator for $1 \mathrm{~h}$ and centrifuged $\left(10,000 \mathrm{~g}, 10 \mathrm{~min}, 20^{\circ} \mathrm{C}\right)$. Supernatants were diluted to respectively $2.5 \mathrm{~g} \mathrm{l}^{-1}$ and $1 \mathrm{~g} \mathrm{l}^{-1}$, and $30 \mu \mathrm{l}$ was mixed with $30 \mu \mathrm{l}$ of ETEC K88 suspension and $30 \mu \mathrm{l}$ of brush border cell suspensions. The mixture was incubated at room temperature with continuous gentle shaking $\left(100 \mathrm{~min}^{-1}\right)$ in a plate shaker (Plate shaker KL2, Edmund Bühler GmbH, Hechingen, Germany) for $1 \mathrm{~h}$. The number of bacterial cells, adhering to 12 individual brush border cells, was determined by phase contrast microscopy (magnification 1000×). The proportion of adhesion was calculated as the average number of ETEC K88 per brush border cell, relatively to the adhesion with the positive control.

\subsection{Statistical analyses}

The significance of the bioactivity experiments was evaluated by comparing means using one or two-way ANOVA, followed by the Bonferroni post-test. Results were expressed as mean \pm SEM and differences were considered significant at $P<0.05$. Statistics were performed with Graphpad Prism version 4.03 for Windows (Graphpad Software, San Diego, CA, USA).

\section{Results}

\subsection{Bioactivity of soya bean tempe towards different ETEC bacteria}

Several strains of ETEC bacteria, isolated from piglets suffering from diarrhoea found in different farms in the Netherlands were used (Table 1). These strains were tested for their adherence to brush border cells as represented in Fig. 1. Strain ID 1000 and ID 1084 were used as positive and negative control strains, respectively (Roubos-van den Hil et al., 2009). Incubation of brush border cells with strain ID 1000 resulted in an adhesion of $10.3 \pm 0.66$ 


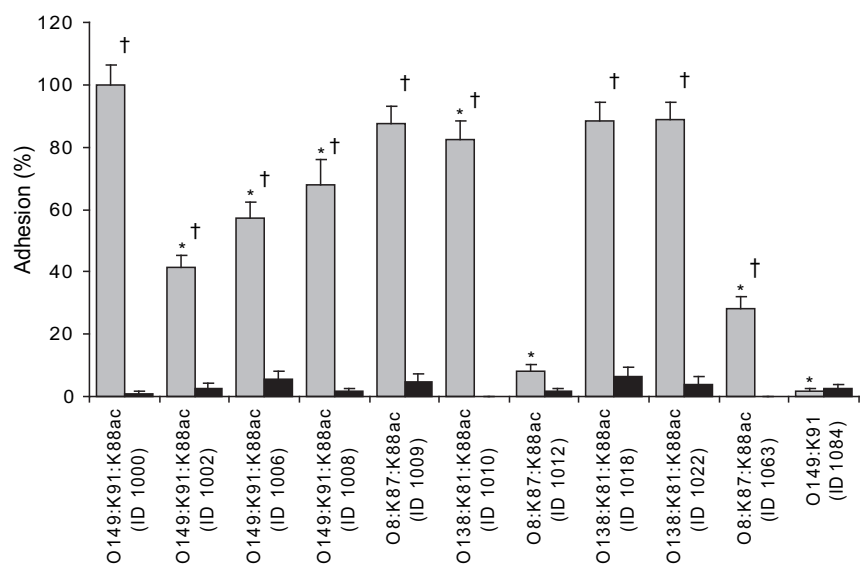

Fig. 1. Adhesion of different ETEC strains to piglet brush border cells. Gray bars represent adhesion without addition and black bars with addition of tempe extract $\left(2.5 \mathrm{~g} \mathrm{l}^{-1}\right)$. Bars represent mean values, expressed as \% adhesion compared to the positive control (strain ID 1000) of 12 individual brush borders. Error bars represent SEM. Bars with asterisk $\left(^{*}\right)$ differ significantly from strain ID 1000. Bars with $\dagger$ represent a significant effect of addition of tempe extract.

(mean \pm SEM) ETEC cells to one brush border cell. This value was used as a reference representing 100\% adherence. Strain ID 1084 is known as a negative strain, which means that the bacteria were not capable of adhering to brush border cells. All other tested ETEC strains adhered to the brush border cells, except strain 1012. Among the other strains differences were observed in the number of ETEC adhering to a brush border cell, but incubation of the brush border cells in presence of tempe and these ETEC bacteria always resulted in very low adhesion values (Fig. 1). The resulting adhesion values were of the same order as observed previously for strain ID 1000 (Roubos-van den Hil et al., 2009).

\subsection{Monitoring tempe fermentation from different substrates}

After fermentation of different substrates with $R$. microsporus (LU 573), all substrates except red beans and wheat were fully fermented, i.e. overgrown and penetrated by fungal mycelium.
The visual appearance of the fermented substrates was a dense cotton mycelium that bound the individual legumes or cereals to a cake-like product. Also, the smell of these products was fresh and typical of good quality tempe. In the red bean and wheat product the mould had not fully penetrated the centre of the product, but mainly grown at the outside, which resulted in a loose cake, which was easy to break.

Table 3 shows the fermentation parameters that were analyzed. During cooking the $\mathrm{pH}$ had increased slightly (data not shown) and after $48 \mathrm{~h}$ of fermentation the $\mathrm{pH}$ was increased in all of the fermented substrates except in oat. Solubility increased in all fermented substrates, with a maximum of 7 times the initial amount of soluble material in fermented green peas. The amount of free amino nitrogen was increased for all substrates during fermentation. In the legumes the amount of free amino nitrogen before and after fermentation was higher than in the cereals, but also the amount of proteins in the legume substrates was higher. All substrates showed an increase of at least 2 times the amount of free amino nitrogen, except the wheat and red bean tempe, which was in accordance with our expectations based on the poor mycelium development in these products. The level of reducing sugars also increased strongly during tempe fermentation, especially in the non-soya substrates.

Microbiological observations during the fermentation showed strong growth of LAB, up to $\log 9 \mathrm{CFU} \mathrm{g}^{-1}$, in the two soya products and the cowpea product. In the other substrates also growth of LAB and total mesophilic aerobic bacteria was observed, but values were lower, i.e. $\log 6-7 \mathrm{CFU} \mathrm{g}^{-1}$.

\subsection{Bioactivity of tempe prepared with different substrates}

Bioactivity of the different cooked substrates are shown in Fig. 2. Whereas some significant extent of adhesion inhibition was observed for the cooked legumes, the cooked cereal extracts did not inhibit adherence significantly. After fermentation the bioactivity of the tempe extracts increased significantly with all legume substrates, whereas the fermented cereals still showed no activity. Soya, cowpea and green pea extracts inhibited the adhesion to values lower than $20 \%$ of the positive control. The red beans substrate showed some adhesion inhibition, but this activity was

Table 3

Fermentation characteristics of leguminous and cereal grains fermented with Rhizopus microsporus (LU 573).

\begin{tabular}{|c|c|c|c|c|c|c|c|c|}
\hline & & $\mathrm{pH}$ & $\begin{array}{l}\text { Solubility } \\
\text { (g/100 g } \\
\text { dry matter) }\end{array}$ & $\begin{array}{l}\text { Amino nitrogen (mmol } \\
\text { free amino group } / 100 \mathrm{~g} \\
\text { dry matter) }\end{array}$ & $\begin{array}{l}\text { Protein }(\mathrm{g} / 100 \mathrm{~g} \\
\text { dry matter) }\end{array}$ & $\begin{array}{l}\text { Reducing sugars } \\
\text { (mg/100 g } \\
\text { dry matter) }\end{array}$ & $\begin{array}{l}\mathrm{LAB}^{\mathrm{a}} \\
\log \\
\mathrm{CFU} / \mathrm{g}\end{array}$ & $\begin{array}{l}\text { TVC }^{\mathrm{b}} \\
\log \\
\text { CFU/g }\end{array}$ \\
\hline \multirow[t]{2}{*}{ Soya } & Cooked & 4.6 & 7.0 & 15.0 & 41.8 & 192.1 & 2.2 & 2.3 \\
\hline & Fermented (48 h) & 6.0 & 19.0 & 49.4 & 43.8 & 464.8 & 8.7 & 8.8 \\
\hline \multirow[t]{2}{*}{ Organic soya } & Cooked & 4.7 & 4.0 & 17.1 & 48.3 & 218.5 & 2.3 & 2.3 \\
\hline & Fermented (48 h) & 5.8 & 15.0 & 44.7 & 48.2 & 517.6 & 9.2 & 9.2 \\
\hline \multirow[t]{2}{*}{ Cowpea } & Cooked & 5.0 & 3.0 & 10.7 & 22.2 & 180.6 & 3.5 & 3.3 \\
\hline & Fermented (48 h) & 5.8 & 12.0 & 23.7 & 25.9 & 818.5 & 8.5 & 8.5 \\
\hline \multirow[t]{2}{*}{ Green pea } & Cooked & 5.2 & 2.0 & 11.3 & 22.5 & 275.9 & $<2$ & $<2$ \\
\hline & Fermented (48 h) & 5.9 & 14.0 & 23.2 & 24.6 & 857.4 & 6.6 & 6.8 \\
\hline \multirow[t]{2}{*}{ Red bean } & Cooked & 6.7 & 8.0 & 10.0 & 22.6 & 50.0 & $<2$ & 3.6 \\
\hline & Fermented (48 h) & 7.0 & 14.0 & 15.6 & 22.9 & 675.0 & 6.4 & 6.5 \\
\hline \multirow[t]{2}{*}{ Wheat } & Cooked & 5.5 & 3.0 & 3.3 & 13.6 & 325.9 & $<2$ & $<2$ \\
\hline & Fermented (48 h) & 6.5 & 12.0 & 5.8 & 13.3 & 855.1 & 6.2 & 6.7 \\
\hline \multirow[t]{2}{*}{ Oat } & Cooked & 5.2 & 5.0 & 5.3 & 15.0 & 194.9 & 3.3 & 3.7 \\
\hline & Fermented (48 h) & 5.1 & 15.0 & 11.4 & 18.8 & 970.8 & 6.2 & 6.5 \\
\hline \multirow[t]{2}{*}{ Barley } & Cooked & 4.5 & 3.0 & 2.1 & 9.7 & 25.9 & 2.1 & 2.2 \\
\hline & Fermented (48 h) & 5.3 & 9.0 & 8.1 & 11.2 & 887.5 & 6.3 & 7.6 \\
\hline
\end{tabular}

aAB: Lactic Acid Bacteria

b TVC: Total Viable Count of mesophilic aerobic bacteria. 


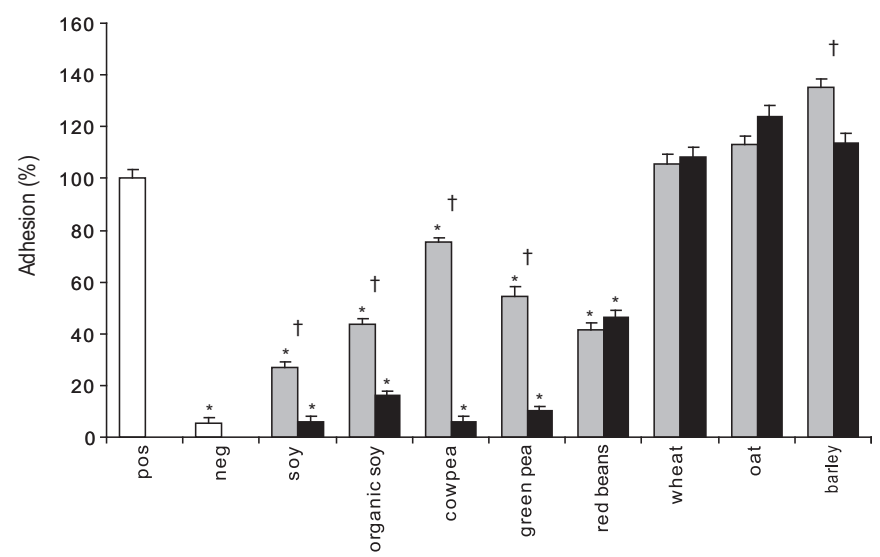

Fig. 2. Adhesion of ETEC K88 to brush border cells with addition of extracts of cooked and fermented substrates. White bars represent controls without any addition of extract; Gray bars represent extracts of cooked legumes and cereals $\left(2.5 \mathrm{~g} \mathrm{l}^{-1}\right)$; Black bars represent the fermented legumes and cereals $\left(2.5 \mathrm{~g} \mathrm{l}^{-1}\right)$. Bars represent mean values, expressed as \% adhesion compared to the positive control of 12 individual brush borders. Error bars represent SEM. Bars with asterisk $\left(^{*}\right)$ inhibit adhesion significantly compared with the positive control. Bars with $\dagger$ represent a significant difference between cooked and fermented substrates.

not increased as a result of fermentation, which could very well be related to the incomplete fermentation of this substrate.

\subsection{Soya bean fermentation with different microorganisms}

Cooked and sterilized soya beans were inoculated with pure starter cultures of different microorganisms, namely 2 Lactobacillus spp., 3 Bacillus spp., 6 yeasts and 8 mould strains (Table 2). After a $48 \mathrm{~h}$ incubation period, the fermented samples were analyzed and compared with the cooked substrates, as shown in Table 4.

The two tested LAB strains, that had been isolated from soya soaking water, grew to $9 \log \mathrm{CFU} \mathrm{g}{ }^{-1}$, a level that was also observed in regular tempe (Table 3). During incubation the $\mathrm{pH}$ decreased and a distinct sour odour was observed. All reducing sugars were utilized, but the levels of free amino nitrogen did not change.

After incubation with the Bacillus spp., soya beans were sticky and an ammoniacal odour was observed. The Bacillus spp. were able to grow up to $10 \log \mathrm{CFU} \mathrm{g} \mathrm{g}^{-1}$, while the $\mathrm{pH}$ and levels of free amino nitrogen and reducing sugars had increased.

All yeasts were able to grow after inoculation to $8-9 \log \mathrm{CFU} \mathrm{g}^{-1}$. In contrast to the other strains, the $\mathrm{pH}$ of soya beans incubated with Saccharomyces cerevisiae (LU 1251) and Candida glabrata (LU 1253) was not increased during fermentation. Saccharomycopsis fibuligera (LU 677) increased the levels of free amino nitrogen and reducing sugars. Candida intermedia (LU 121), Trichosporon beigelii (LU 692) and S. cerevisiae (LU 1251) caused an increase of reducing sugars. The other yeast strains (Pichia guilliermondii LU 502 and C. glabrata LU 1253) decreased the level of reducing sugars, but had no effect on free amino nitrogen levels.

All mould strains were able to grow, and bound the soya beans together to a firm cake. During fermentation all moulds caused an increase of reducing sugars and free amino nitrogen levels.

\subsection{Bioactivity of soya beans fermented with different microorganisms}

The bioactivity of the fermented soya beans is shown in Fig. 3 . All moulds and Bacillus fermented soya beans showed adhesion inhibition of more than $90 \%$. Lactobacillus fermented soya beans caused no inhibition of adhesion. Of the yeast fermented soya beans only those with S. fibuligera (LU 677) and T. beigelii (LU 692) showed inhibition of adhesion.

\section{Discussion}

Diarrhoeal disease in piglets is frequently due to infection by ETEC. It causes severe, watery diarrhoea especially in suckling and

Table 4

Fermentation characteristics of soya beans fermented with a range of bacteria, yeasts and moulds.

\begin{tabular}{|c|c|c|c|c|c|}
\hline Sample type & $\mathrm{pH}$ & $\begin{array}{l}\text { Amino nitrogen } \\
\text { (mmol free amino } \\
\text { group/100 g dry matter) }\end{array}$ & $\begin{array}{l}\text { Reducing sugars } \\
\text { (mg/100 g dry matter) }\end{array}$ & $\begin{array}{l}\text { Inoculation } \\
(\log C F U / g)\end{array}$ & $\begin{array}{l}\text { Incubated } 48 \mathrm{~h} \\
(\log \mathrm{CFU} / \mathrm{g})\end{array}$ \\
\hline Cooked & 6.6 & 19.9 & 59.2 & - & - \\
\hline \multicolumn{6}{|l|}{ Lactobacillus } \\
\hline LU $848^{a}$ & 5.1 & 18.4 & 0.0 & 5.3 & 9.3 \\
\hline LU 852 & 5.1 & 18.4 & 0.0 & 5.1 & 9.2 \\
\hline \multicolumn{6}{|l|}{ Bacillus } \\
\hline LU 810 & 7.0 & 41.9 & 456.1 & 4.6 & 10.0 \\
\hline LU 812 & 6.7 & 26.7 & 411.7 & 4.5 & 9.8 \\
\hline LU 814 & 7.6 & 74.9 & 172.5 & 4.4 & 9.4 \\
\hline \multicolumn{6}{|l|}{ Yeasts } \\
\hline LU 121 & 6.9 & 17.3 & 282.5 & 5.4 & 8.9 \\
\hline LU 502 & 6.9 & 12.9 & 0.0 & 6.3 & 9.5 \\
\hline LU 677 & 7.2 & 38.4 & 114.5 & 4.4 & 8.3 \\
\hline LU 692 & 6.8 & 19.3 & 150.6 & 3.7 & 7.7 \\
\hline LU 1251 & 6.3 & 15.8 & 232.6 & 5.6 & 8.7 \\
\hline LU 1253 & 6.5 & 20.6 & 7.4 & 5.5 & 8.5 \\
\hline \multicolumn{6}{|l|}{ Moulds } \\
\hline LU 361 & 7.0 & 33.1 & 445.6 & $\mathrm{ND}^{\mathrm{b}}$ & ND \\
\hline LU 365 & 7.0 & 37.0 & 544.2 & ND & ND \\
\hline LU 573 & 6.7 & 51.3 & 205.0 & ND & ND \\
\hline LU 575 & 6.4 & 68.6 & 718.3 & ND & ND \\
\hline LU 581 & 6.5 & 52.6 & 537.8 & ND & ND \\
\hline LU 2036 & 7.0 & 54.7 & 125.1 & ND & ND \\
\hline LU 2040 & 7.0 & 63.1 & 235.5 & ND & ND \\
\hline LU 2041 & 6.6 & 60.1 & 515.7 & ND & ND \\
\hline
\end{tabular}

a See Table 2 for names of microorganisms.

b ND, not determined. 


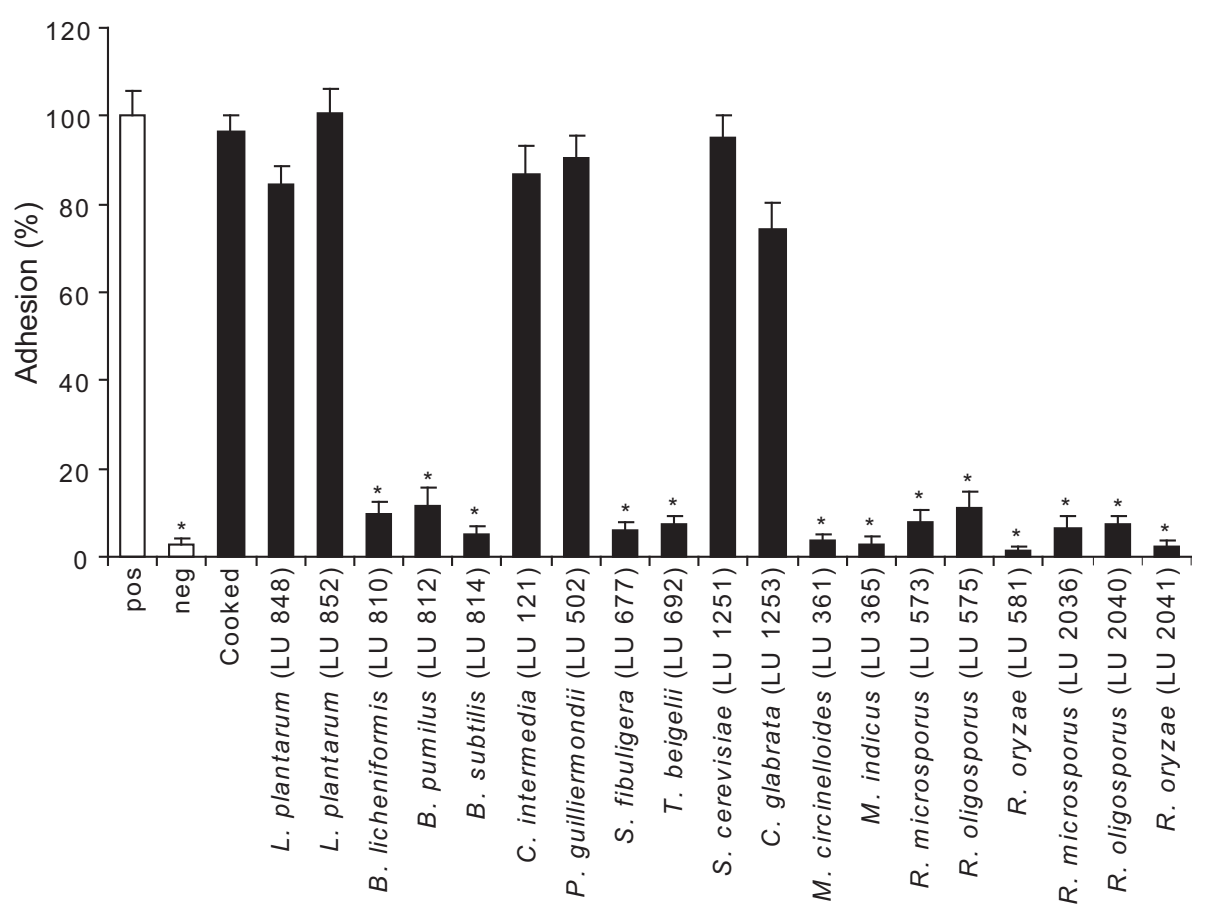

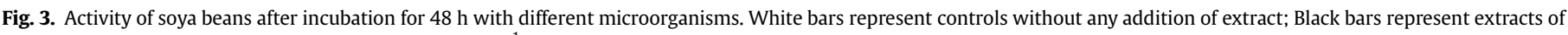

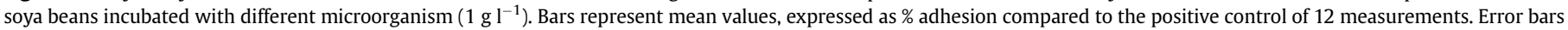
represent SEM. Bars with asterisk $\left(^{*}\right)$ inhibit adhesion significantly compared with the positive control.

weaned piglets (Nagy and Fekete, 2005). ETEC is also recognized as one of the most frequent causes of childhood diarrhoea in developing countries, and of traveler's diarrhoea (Bhan, 2000). We tested the bioactivity of soya bean tempe on a range of ETEC strains of different serogroups with different fimbrial adhesins and observed that tempe extracts decrease the adhesion of most tested ETEC on brush border cells. Thus, tempe extracts can prevent intestinal cells being colonized by different strains of ETEC causing diarrhoea in piglets.

During fermentation of soya beans with Rhizopus spp. diverse chemical modifications take place. During the soaking stage the $\mathrm{pH}$ of the soaked substrates was lowered by LAB. A high number of actively acidifying LAB mixed culture was obtained by using the back-slop technique (data not shown). The soaking step is important for the quality of the tempe, because it prevents the growth of spoilage causing bacteria (Ashenafi and Busse, 1991; Nout et al., 1987). During cooking of beans the $\mathrm{pH}$ will start to increase, which continues during fermentation. This is a result of proteolysis and the release of ammonia following utilization of amino acids as carbon and energy source by the mould (Sarkar et al., 1993). Oats did not show a $\mathrm{pH}$ increase, which can be due to an initial $\mathrm{pH}$ decrease during the first hours of fermentation during which sugars, and not proteins were used as substrates for growth. The solubility of all substrates increased during fermentation, which is due to the enzymatic degradation of macromolecules into substances of lower molecular weight with a higher solubility (De Reu et al., 1995; Kiers et al., 2000a; Nout and Rombouts, 1990). Enzymatic degradation was also evidenced by the increased levels of free amino groups and reducing sugars. Astuti (2000) showed that the effect of fermentation on total nitrogen content is negligible, but increases of free amino acids take place during fermentation. Higher levels of carbohydrates are found in the non-soya substrates, which upon degradation, result in higher values of reducing sugars. Research conducted elsewhere (Ashenafi, 1994; Mulyowidarso et al., 1990; Samson et al., 1987) indicated that in tempe total bacterial counts can reach $10^{9} \mathrm{CFU} \mathrm{g} \mathrm{g}^{-1}$ and $\mathrm{LAB}$ can reach levels of $10^{8}-10^{9} \mathrm{CFU} \mathrm{g}^{-1}$, which is comparable with our observations in soya and cowpea tempe. The other substrates also supported microbial growth, but remarkably less, for example in barley tempe the counts were comparable with data reported by Feng et al. (2005). Different levels of growth achieved in diverse substrates are assumedly associated with their individual nutrient composition.

Bioactivity was measured in all extracts of leguminous tempe and this activity increased during fermentation. In contrast, the cereal-derived tempe products showed no bioactivity at all. It appears that during fermentation an active component was released or formed by enzymatic breakdown from leguminous substrates. Mould biomass itself has no bioactivity since wellgrown cereal-derived tempe lacked inhibition activity. The active component(s) is, therefore, specific for legumes. This could be related to the higher protein content or the protein composition in legume seeds. Another remarkable difference is the relatively high amount of isoflavones present in legumes, which are not (or at very low levels) present in cereals (Liggins et al., 2002). Also the cell wall is different, monocotyledons (cereals) contain cellulose fibrils in close association with arabinoxylans, whereas dicotyledons (legumes) contain cellulose with pectin and xyloglucans (Harris and Smith, 2006).

Tempe is traditionally fermented with moulds, mainly Rhizopus oryzae, Rhizopus oligosporus, R. microsporus or Mucor indicus, of which the functionality has been reported earlier (Nout and Kiers, 2005; Samson et al., 1987). In addition, tempe contains a range of bacteria such as LAB, Bacillus spp. and yeasts (Nout and Rombouts, 1990; Samson et al., 1987), of which less is known about their function in the fermentation.

Before inoculation with the pure microbial strains the soya beans were soaked overnight at $4{ }^{\circ} \mathrm{C}$ instead of $30{ }^{\circ} \mathrm{C}$ to avoid fermentative acidification, since this acidification could influence the growth of acid sensitive strains. When testing the effect of tempe-derived pure microbial strains on soya beans, we observed that Lactobacillus spp. assimilated all available sugars to form lactic acid as indicated by concomitant $\mathrm{pH}$ decrease. The modification of 
soya beans with Bacillus spp. can be compared with that during the fermentation of Kinema, a traditional Bacillus fermented soya bean food in India and Nepal. These fermentations are characterized by extensive hydrolysis of proteins into amino acids, peptides and ammonia and a typical sticky appearance of the soya beans (Kiers et al., 2000b; Nout et al., 1998; Sarkar et al., 1993). Our observations of Bacillus fermented soya beans were similar to Kinema. The occurrence of yeasts has been reported in tempe products as yeasts can grow well in mixed microflora with lactic acid bacteria and filamentous fungi, but no yeasts species are specifically associated with tempe (Ashenafi and Busse, 1991; Feng et al., 2007b; Samson et al., 1987). Our observations show that yeasts found in tempe were able to grow on soya beans and some yeasts were also able to interact (by degrading macromolecules) with the soya beans. The soya beans fermented with the different mould strains were similar to tempe prepared following the usual process, confirming that tempe can be made without co-inoculants.

All Bacillus spp., yeast strains LU 677 and LU 692 and all tested mould strains caused inhibition of the ETEC adhesion after incubation with soya beans. Thus, activity was not related to a specific microorganism, but instead the degradation of certain macromolecules is needed to release or form bioactive component(s) from the soya beans.

In conclusion, tempe derived from leguminous seeds is bioactive, i.e. reduces adhesion of ETEC to piglet brush border cells, whereas tempe derived from cereals is inactive. The bioactive component(s) is released or formed during fermentation from leguminous matter. The capability to release or form bioactive component(s) is not specific for one microbial species. A range of ETEC strains was shown to be sensitive for the bioactive component, making this bioactivity of potential interest for application in animal husbandry.

Further research to elucidate the nature of the bioactive component in fermented leguminous seeds will be required.

\section{Acknowledgement}

This research was financially supported by the Graduate School VLAG, Wageningen University, Wageningen, The Netherlands. The authors thank Ank van Zijderveld-van Bemmel for providing the ETEC strains.

\section{References}

Ashenafi, M., 1994. Microbiological evaluation of tofu and tempeh during processing and storage. Plant Foods Hum. Nutr. 45, 183-189.

Ashenafi, M., Busse, M., 1991. The microflora of soak water during tempeh production from various beans. J. Appl. Bacteriol. 70, 334-338.

Astuti, 2000. Tempe, a nutritious and healthy food from Indonesia. Asia Pac. J. Clin. Nutr. 9, 322-325

Bhan, M.K., 2000. Current and future management of childhood diarrhoea. Int. J. Antimicrob. Agents 14, 71-73.

De Reu, J.C., ten Wolde, R.C., de Groot, J., Nout, M.J.R., Rombouts, F.M., Gruppen, H., 1995. Protein hydrolysis during soybean tempe fermentation with Rhizopus oligosporus. J. Agric. Food Chem. 43, 2235-2239.
Egounlety, M., 2001. Sensory evaluation and nutritive value of tempe snacks in West Africa. Int. J. Food Prop. 4, 513-522.

Eklund-Jonsson, C., Sandberg, A., Alminger, M.L., 2006. Reduction of phytate content while preserving minerals during whole grain cereal tempe fermentation. J. Cereal Sci. 44, 154-160.

Feng, X.M., Eriksson, A.R., Schnürer, J., 2005. Growth of lactic acid bacteria and Rhizopus oligosporus during barley tempeh fermentation. Int. J. Food Microbiol. 104, 249-256.

Feng, X.M., Larsen, T.O., Schnürer, J., 2007a. Production of volatile compounds by Rhizopus oligosporus during soybean and barley tempeh fermentation. Int. J. Food Microbiol. 113, 133-141.

Feng, X.M., Passoth, V., Eklund-Jonsson, C., Alminger, M.L., Schnürer, J., 2007b. Rhizopus oligosporus and yeast co-cultivation during barley tempeh fermentation - nutritional impact and real-time PCR quantification of fungal growth dynamics. Food Microbiol. 24, 393-402.

Green, F., Clausen, C.A., Highley, T.L., 1989. Adaptation of the Nelson-Somogyi reducing-sugar assay to a microassay using microtiter plates. Anal. Biochem. 182, 197-199.

Hachmeister, K.A., Fung, D.Y.C., 1993. Tempeh - a mold-modified indigenous fermented food made from soybeans and/or cereal grains. Crit. Rev. Microbiol. 19, 137-188.

Han, B., Kiers, J.L., Nout, M.J.R., 1999. Solid-substrate fermentation of soybeans with Rhizopus spp.: comparison of discontinuous rotation with stationary bed fermentation. J. Biosci. Bioeng. 88, 205-209.

Harris, P.J., Smith, B.G., 2006. Plant cell walls and cell-wall polysaccharides: structures, properties and uses in food products. Int. J. Food Sci. Technol. 41, 129-143.

Kiers, J.L., Meijer, J.C., Nout, M.J.R., Rombouts, F.M., Nabuurs, M.J.A., Van der Meulen, J., 2003. Effect of fermented soya beans on diarrhoea and feed efficiency in weaned piglets. J. Appl. Microbiol. 95, 545-552.

Kiers, J.L., Nout, M.J.R., Rombouts, F.M., 2000a. In vitro digestibility of processed and fermented soya bean, cowpea and maize. J. Sci. Food Agric. 80, 1325-1331.

Kiers, J.L., Nout, M.J.R., Rombouts, F.M., Nabuurs, M.J.A., Van der Meulen, J., 2002. Inhibition of adhesion of enterotoxic Escherichia coli K88 by soya bean tempe. Lett. Appl. Microbiol. 35, 311-315.

Kiers, J.L., Van Laeken, A.E., Rombouts, F.M., Nout, M.J.R., 2000b. In vitro digestibility of Bacillus fermented soya bean. Int. J. Food Microbiol. 60, 163-169.

Liggins, J., Mulligan, A., Runswick, S., Bingham, S.A., 2002. Daidzein and genistein content of cereals. Eur. J. Clin. Nutr. 56, 961-966.

Mugula, J.K., Lyimo, M., 2000. Evaluation of the nutritional quality and acceptability of sorghum-based tempe as potential weaning foods in Tanzania. Int. J. Food Sci. Nutr. 51, 269-277.

Mulyowidarso, R.K., Fleet, G.H., Buckle, K.A., 1990. Association of bacteria with the fungal fermentation of soybean tempe. J. Appl. Bacteriol. 68, 43-47.

Nagy, B., Fekete, P.Z., 2005. Enterotoxigenic Escherichia coli in veterinary medicine. Int. J. Med. Microbiol. 295, 443-454.

Nataro, J.P., Kaper, J.B., 1998. Diarrheagenic Escherichia coli. Clin. Microbiol. Rev. 11, 142-201.

Nout, M.J.R., Bakshi, D., Sarkar, P.K., 1998. Microbiological safety of kinema, a fermented soya bean food. Food Control 9, 357-362.

Nout, M.J.R., De Dreu, M.A., Zuurbier, A.M., Bonants-Van Laarhoven, T.M.G., 1987. Ecology of controlled soyabean acidification for tempe manufacture. Food Microbiol. 4, 165-172.

Nout, M.J.R., Kiers, J.L., 2005. Tempe fermentation, innovation and functionality: update into the third millenium. J. Appl. Microbiol. 98, 789-805.

Nout, M.J.R., Rombouts, F.M., 1990. Recent developments in tempe research. J. Appl Bacteriol. 69, 609-633.

Roubos-van den Hil, P.J., Nout, M.J.R., Beumer, R.R., van der Meulen, J., Zwietering, M.H., 2009. Fermented soya bean (tempe) extracts reduce adhesion of enterotoxigenic Escherichia coli to intestinal epithelial cells. J. Appl. Microbiol. 106, 1013-1021.

Samson, R.A., Van Kooij, J.A., De Boer, E., 1987. Microbiological quality of commercial tempeh in the Netherlands. J. Food Prot. 50, 92-94.

Sarkar, P.K., Cook, P.E., Owens, J.D., 1993. Bacillus fermentation of soybeans. World J. Microbiol. Biotechnol. 9, 295-299.

Sellwood, R., Gibbons, R.A., Jones, G.W., Rutter, J.M., 1975. Adhesion of enteropathogenic Escherichia coli to pig intestinal brush borders: the existence of two pig phenotypes. J. Med. Microbiol. 8, 405-411. 